\title{
Partial purification and characterisation of polyphenol oxidase from faba bean (Vicia faba) coat
}

\author{
Sebnem Selen Isbilir ${ }^{1}$, Aysenur Gulo Yediel ${ }^{1,2}$
}

\author{
1 - Trakya University, Edirne, Turkey \\ 2 - Altis Clinical Research Organisation, Sariyer/Istanbul, Turkey
}

\section{Keywords:}

Faba bean

Purification

Polyphenol oxidase

Stability

\section{Article history:}

Received 20.10.2021

Received in revised

form 24.11.2021

Accepted 30.12.2021

\section{Corresponding \\ author:}

Sebnem Selen Isbilir

E-mail:

sebnemselenisbilir@ trakya.edu.tr

DOI: $10.24263 / 2310-$ 1008-2021-9-2-5

\section{Abstract}

Introduction. The aim of this study is to isolate polyphenol oxidase (PPO) enzyme from faba bean coat, and to determine its optimum $\mathrm{pH}$ and temperature, $\mathrm{K}_{\mathrm{m}}$ and $\mathrm{V}_{\max }$ parameters, to investigate biochemical properties such as $\mathrm{pH}$ and temperature stability, substrate selectivity, storage stability of enzyme, and also effects of some metals and inhibitors on its activity.

Materials and methods. The protein precipitation was done by using ammonium sulfate salt and then, dialysis was performed to remove salt ions after precipitation. Protein content of the samples at each step was determined according to Bradford method, and enzymatic activity was determined spectrophotometrically.

Results and discussion. The properties of PPO enzyme, which was purified 3.1-fold, were determined using catechol as substrate. $\mathrm{K}_{\mathrm{m}}$ and $\mathrm{V}_{\max }$ values of the enzyme were determined to be $5.53 \mathrm{mM}$ and $4424,58 \mathrm{U}_{\mathrm{ml}}^{-1} \mathrm{~min}^{-1}$, respectively. The enzyme showed the highest activity at $\mathrm{pH}$ 5.0 and $10{ }^{\circ} \mathrm{C}$. It saved about $60 \%$ of its activity after a 30 min incubation period at its optimum $\mathrm{pH}$. Substrate specificity of PPO was studied using eight substrates including pyrogallol and 4-methylcatechol. When the thermal stability profile was examined in the $10-60{ }^{\circ} \mathrm{C}$ temperature range, it exhibited more than $50 \%$ of its activity in the range of $10-40{ }^{\circ} \mathrm{C}$ after 1 hour of incubation. While L-ascorbic acid, sodium sulfite and L-cysteine showed strong inhibitory effects, the studied metals showed variable effects on the enzyme activity.

Conclusions. The polyphenol oxidase enzyme activity causes undesirable changes and nutritional value loss in some fruits and vegetables. The results obtained provide information about faba bean PPO and give clues to the effective methods for controlling browning during storage. 


\section{- Food Technology -}

\section{Introduction}

The Fabaceae, also known as the Leguminosae, is a large, economically and medicinally important family. Because natural nitrogen fixation is performed by Rhizobium bacteria, which can be found in the root nodules of leguminous plants. Moreover, the dietary consumption of legumes is associated with lower incidence of chronic degenerative diseases (Turco et al., 2016). Broad bean or faba bean (Vicia faba) is a one-year plant from the Fabaceae family and faba beans used as a vegetable which consumed fresh and green or dried. This plant has an important place in diets of Chinese, English, Turkish and Mediterranean because of a useful source of polyphenols (Turco et al., 2016). Faba bean has L-DOPA (L-3,4-dihydroxyphenylalanine) content (Topal and Bozoglu, 2016; Mohseni and Golshani, 2013) which medically used in the treatment of Parkinson's disease. In the technology, it and some other Fabaceae species is used in the production of L-DOPA (Goyoaga et al., 2008). However, faba beans are also used as additives in animal feeds due to their high protein content. Field bean (Vicia faba var minor) especially is a good protein source for animal feedstuffs (Antongiovanni et al., 2002; Perella et al., 2009). Because of the symbiosis with nodule-forming bacteria (Rizobium), legumes with high nitrogen fixation have an important place in agriculture as "green manure" (Ayaz and Sokmen, 2015). In the study carried out on the use of faba bean as a green manure in broccoli cultivation, it was observed that increased broccoli yield and some properties (Yilmaz and Sahin, 2014).

In general, the chemical composition of plants is significantly different due to some factors that cover types of seed (genetic), age, and environment, such as soil conditions and climate, as well as weather and growing conditions, such as fertilization, pesticides and pests. One of the important chemical components of plants is the PPO enzyme. It is found in different parts of plants including roots, leaves, flowers and vascular tissues (Constabel and Barbehenn, 2008). PPO catalyzes the hydroxylation of monophenols to o-diphenols and the oxidation of o-diphenols to o-quinones in the presence of molecular oxygen. Copper is required as a prosthetic group to its activity. There are three classes of enzymes belonging to the PPOs: catechol oxidase (EC 1.10.3.1; 1,2-benzenediol: oxygen oxidoreductase), laccase (EC 1.10.3.2; p-benzenediol: oxygenoxidoreductase) and tyrosinase (EC 1.14.18.1; monophenol monooxygenase, cresolase) (NC-IUBMB, 2019). PPOs are commonly found in the plant kingdom and are a major cause of browning during the harvesting and storage of many fruits and vegetables. In the other hand, the oxidative enzyme levels including PPO are affected by plant-insect interactions. When plants are injured by insects, the reactive oxygen species are overproduced and the plants overcome this oxidative stress by producing an efficient enzymatic antioxidant defense system (Nabity et al., 2006; Chen et al., 2009; He et al., 2011; Panadare and Rathod, 2018). Therefore polyphenol oxidase is both involved in oxidation phenolic and plant defense system.

The faba bean coat, planted in Thrace region, is currently growing in popularity due to their premium texture and taste. However, there are no reports on the polyphenol oxidase from these cultivars, and also on pod (outer shell) of the plant. Therefore, the aim of this research was to isolate and characterize the biochemical properties of PPO from faba bean coat grown in Turkey. Although the studies on the property of PPO from various vegetables and fruits have also been carried out in the past, in the literature no studies have been conducted on broad bean coat except few studies on the isolation and characterization of PPO from broad bean leaf. 


\section{Material and method}

\section{Plant material and isolation of enzyme}

Faba bean that planted at Edirne province in Turkey was purchased from a local market. The plants were washed and the beans were removed from their coats. The coats (outer shell) were used for enzyme extraction. Three hundred gram fresh coats were homogenized in 0.1 M phosphate buffer ( $\mathrm{pH}$ 6.0) containing polyvinyl pyrolidone and Triton X-100 for 1 min using Waring blender at room temperature. Then the homogenate was filtered through cheesecloth. The filtrate was centrifuged (Heraeus Biofuge Stratos, Osterode-Germany) at $10,000 \mathrm{rpm}$ and $+4{ }^{\circ} \mathrm{C}$ for $20 \mathrm{~min}$ to remove plant residues. The supernatant was called "crude extract" and used as enzyme source for further study.

\section{Partial purification of polyphenol oxidase}

The crude extract of polyphenol oxidase enzyme was precipitated by slowly adding solid ammonium sulphate for $30 \%$ saturation at $4{ }^{\circ} \mathrm{C}$ into it. The protein precipitated was collected by centrifugation at $10,000 \mathrm{rpm}$ for $45 \mathrm{~min}$ at $4{ }^{\circ} \mathrm{C}$. Supernatant was used for further fractionation at between $30-65 \%$ and $65-80 \%$ ammonium sulphate saturation. Protein precipitate obtained at each step were dissolved in $0.1 \mathrm{M}$ phosphate buffer ( $\mathrm{pH} \mathrm{6.0)}$ ) and, enzymatic activity and protein determination were performed. The fraction precipitated between 30 and $65 \%$ saturation was showed highest polyphenol oxidase activity. This fraction was dissolved in a small amount of $0.1 \mathrm{M}$ phosphate buffer $(\mathrm{pH}$ 6.0), and dialyzed overnight at $4^{\circ} \mathrm{C}$ in the same buffer on a magnetic stirrer. The dialyzed extract was used as partially purified enzyme source in the experiments.

\section{Assays of enzyme activity and protein determination}

In assay of PPO activity, the $0.1 \mathrm{ml}$ enzyme solution was mixed with $2.9 \mathrm{ml}$ catechol in $0.1 \mathrm{M}$ phosphate buffer ( $\mathrm{pH}$ 6.0) and the increases in absorbance were followed at $420 \mathrm{~nm}$ spectrophotometrically (Thermo Scientific Multiscan Go, Vantaa-Finland). Because the dialysate has colour, a sample blank consisting of enzyme and buffer solutions was prepared for each tube. One unit of polyphenol oxidase activity was defined as the amount of enzyme producing a 0.001 absorbance increase in sample per minute under the standard assay conditions (Soffan et al., 2014).

Protein content of the samples at each step was determined according to Bradford method using bovine serum albumin as a standard (Bradford, 1976).

Determination of optimum $\mathrm{pH}$ and temperature

PPO activity was determined in a $\mathrm{pH}$ range of 3.0-7.0 in $0.1 \mathrm{M}$ citric acid buffer and 5.0-8.0 in $0.1 \mathrm{M}$ phosphate buffer. The activity was carried out using the standard reaction conditions but changing the buffer and, the catechol was used as substrate. The optimum $\mathrm{pH}$ obtained for PPO was used in all other studies.

The activity of PPO was determined at temperatures ranging from 10 to $60{ }^{\circ} \mathrm{C}$. The catechol substrate and citrate buffer ( $\mathrm{pH} 5.0)$ were incubated in the appropriate medium until the selected temperatures were reached. After equilibration of the reaction mixture at the selected temperature, the enzyme solution was added and, the enzyme activity was determined. PPO activity was calculated as percent residual PPO activity at the optimum temperature. 


\section{Substrate specificity and enzyme kinetics}

The substrate specificity of enzyme was investigated by using various phenolic compounds including catechol, 4-methyl catechol, pyrogallol, L-DOPA, gallic acid, chlorogenic acid, 4-methylcatechol, resorcinol and hydroquinone. The substrate solutions were prepared at $0.02 \mathrm{M}$ concentration in citrate buffer $(0.1 \mathrm{M}, \mathrm{pH}=5.0)$ and enzyme activity was determined for each substrate. The relative activities (\%) of each substrate tested were calculated according to the PPO activity of the catechol.

The kinetic constants, optimum $\mathrm{pH}$ and optimum temperature values of the substrates with high activity were determined. The $\mathrm{K}_{\mathrm{m}}$ and $\mathrm{V}_{\max }$ constants were determined from a Lineweaver-Burk plot under the optimum $\mathrm{pH}$ and temperature conditions. The substrates of catechol, 4-methylcatechol and pyrogallol were used at concentrations $5-50 \mathrm{mM}, 10-30 \mathrm{mM}$ and 10-30 $\mathrm{mM}$, respectively.

\section{pH stability}

The PPO enzyme obtained from coats was pre-incubated for 30 minutes and 60 minutes in citrate buffer $(0.1 \mathrm{M}$ at $\mathrm{pH} 5.0,5.5,6.0,6.5,7.0)$. Then residual activity was determined using catechol substrate under the optimal conditions. Enzyme activity was performed under optimum conditions without incubation, and the residual activity of incubated enzyme expressed as relative activity (\%).

\section{Thermal stability}

Enzyme solution was preheated (Wisebath Daihan Shaking Water Bath, Korea) for 15, 30,45 and $60 \mathrm{~min}$ at $10-60^{\circ} \mathrm{C}$. The aliquot of enzyme solution was taken in test tubes and the tubes were cooled in an ice bath. The remaining activity of the enzyme was estimated under standard assay conditions in each case using catechol substrate. PPO activity determined under optimum conditions without waiting for temperature and it was used as the reference. The activity was defined as the percentage of the maximum activity level.

\section{Determination of the effect of metal ions and some chemicals}

The effects of various inhibitors such as L-ascorbic acid, ethylenediamine tetraacetic acid (EDTA), sodium azide, L-cysteine, potassium cyanide and sodium bisulfite on PPO activity were examined by incubating a mixture consisting of the enzyme solution, buffer solution and inhibitors (at $3 \mathrm{mM}$ and $6 \mathrm{mM}$ concentrations,) for $5 \mathrm{~min}$ at room temperature. Enzyme activity without any reagent was then assayed under standard conditions. Enzymatic activities were expressed as relative values with the activity of the enzyme without any reagent.

The metal ion solutions $\left(\mathrm{Cu}^{2+}, \mathrm{Fe}^{2+}, \mathrm{Ca}^{2+}, \mathrm{Mg}^{2+}, \mathrm{Co}^{2+}, \mathrm{Ni}^{2+}\right)$ were prepared at $1 \mathrm{mM}$ and $10 \mathrm{mM}$ concentrations. To research for each metal effect, activity measurements were done under standard conditions using catechol substrate. Enzymatic activity was expressed as relative values (\%) with reference to the activity of the enzyme without any metal ions. 


\section{Results and discussion}

PPO isolation and characterization studies are performed from various sources in order to determine the properties of the enzyme. In the study PPO isolation was made from faba bean coats, and the crude extract was partially purified by applying ammonium sulphate precipitation and dialysis. Proteins precipitated at 30-65\% salt concentration showed the highest PPO activity and, the precipitate was dialysed by the buffer. While the total specific activity of the enzyme in the homogenate was $2072.4 \mathrm{U}$, the total specific activity of the partially purified PPO was 6415.8 U. According to these results, the enzyme was purified 3.1-fold for the faba bean coat. The enzyme purification steps are summarized in Table 1. In the studies about Fabaceae family, it was reported that PPO was purified 3.5-fold for green bean (Phaseolus vulgaris L.) coat and 3.7-fold for green bean pod after $60 \%$ salt precipitation and dialysis (Guo et al., 2009), and 2.1 times from field bean (Dolichos lablab var. lignosus) seeds after 40-80\% salt precipitation (Paul and Gowda, 2000).

Table 1

Steps for polyphenol oxidase from faba bean coat

\begin{tabular}{|c|c|c|c|c|c|c|}
\hline $\begin{array}{c}\text { Partially } \\
\text { purification } \\
\text { steps }\end{array}$ & $\begin{array}{c}\text { Volume } \\
{[\mathbf{m l}]}\end{array}$ & $\begin{array}{c}\text { Protein } \\
{\left[\mathbf{m g . m l}^{-1}\right]}\end{array}$ & $\begin{array}{c}\text { Activity } \\
{\left[\mathbf{U}^{-m^{-1}}{ }^{-1}\right]}\end{array}$ & $\begin{array}{c}\text { Specific } \\
\text { Activity } \\
{\left[\mathbf{U}_{\left.\mathbf{m} \mathbf{g}^{-1} \mathbf{p r t}\right]}\right.}\end{array}$ & $\begin{array}{c}\text { Total } \\
\text { Specific } \\
\text { Activity } \\
{[\mathbf{U}]}\end{array}$ & $\begin{array}{c}\text { Purification } \\
\text { fold }\end{array}$ \\
\hline $\begin{array}{c}\text { Crude extract } \\
\left(\mathrm{NH}_{4}\right)_{2} \mathrm{SO}_{4} \\
(0-30 \%)\end{array}$ & - & 3.75 & 20 & 5.33 & - & - \\
\hline $\begin{array}{c}\left(\mathrm{NH}_{4}\right)_{2} \mathrm{SO}_{4} \\
(30-65 \%)\end{array}$ & - & 10.05 & 78 & 7.76 & - & - \\
\hline Dialysate & 51 & 20.4 & 2568 & 125.8 & 6415.8 & 3.1 \\
\hline
\end{tabular}

$\mathrm{pH}$ is one of the most important factors that influence enzyme activity. PPO optima for faba bean coats was studied using the catechol substrate in two different buffer systems the $\mathrm{pH}$ range among 4.0-8.0. Optimum $\mathrm{pH}$ was determined as $\mathrm{pH} 6.0$ with phosphate buffer and pH 5.0 with citrate buffer (Figure 1). For the pyrogallol, 4-methylcatechol and hydroquinone substrates, the optimum $\mathrm{pH}$ was found to be 5.0 in citrate buffer.

To predict the behaviour of the enzymes, the biochemical characterization of them is searched in the matter of $\mathrm{pH}$ optimum and stability, thermal activation and stability, substrate specificities, inhibitors or activators. $\mathrm{pH}$ is one of the most important factors that influence enzyme activity. Although the optimum $\mathrm{pH}$ of the PPO enzyme varies depending on the plant source, it is seen that it is generally in the range of 4.0-8.0. Different optimum $\mathrm{pH}$ values for PPO obtained from different sources are reported in the literature. It was reported as 6.8-7.2 for green beans (Phaseolus vulgaris L.) (Guo et al., 2009), 4.0 for field bean (Dolichos lablab) seeds (Paul and Gowda, 2000), 6.0 for mung bean leaf (Shin et al., 1997) and 9.0 for soybean (Nagai and Suzuki, 2003) using catechol as substrate.

To determine the effect of temperature on faba bean PPO, enzymatic activity determination was performed at different temperatures. Differences in temperature can affect the activity by changing the solubility of oxygen necessary for the PPO activity or causing changes in the conformation of the enzyme. In the literature, it is seen that the optimum temperature values for PPO generally change in the range of at $10-50{ }^{\circ} \mathrm{C}$. In the study, the activity of PPO was measured at temperatures among $10-60{ }^{\circ} \mathrm{C}$ for catechol (Figure 2), 4- 


\section{— Food Technology ——}

methylcatechol and pyrogallol substrates at optimum $\mathrm{pH}$. The enzyme showed the highest activity at $10{ }^{\circ} \mathrm{C}$ for all substrates, but the studies were carried out at $20^{\circ} \mathrm{C}$ where the next highest activity was observed due to the difficulty of maintaining this temperature $\left(10^{\circ} \mathrm{C}\right)$ as stable. Using catechol as substrate, it has been reported as being at $20-30{ }^{\circ} \mathrm{C}$ for green beans (Phaseolus vulgaris L.) (Guo et al., 2009), $40{ }^{\circ} \mathrm{C}$ for soybean sprouts (Nagai and Suzuki, 2003), $10^{\circ} \mathrm{C}$ for borage plant (Trachystemon orientalis L.) (Alici and Arabaci, 2016), $30^{\circ} \mathrm{C}$ for eggplant (Ng and Wong, 2015), $35^{\circ} \mathrm{C}$ for blueberry (Vaccinium corymbosum $\mathrm{L}$.) (Siddiq and Dolan, 2017), $25^{\circ} \mathrm{C}$ for grape (Onez, 2006) and plums (Prunus domestica) (Ionita et al., 2017).

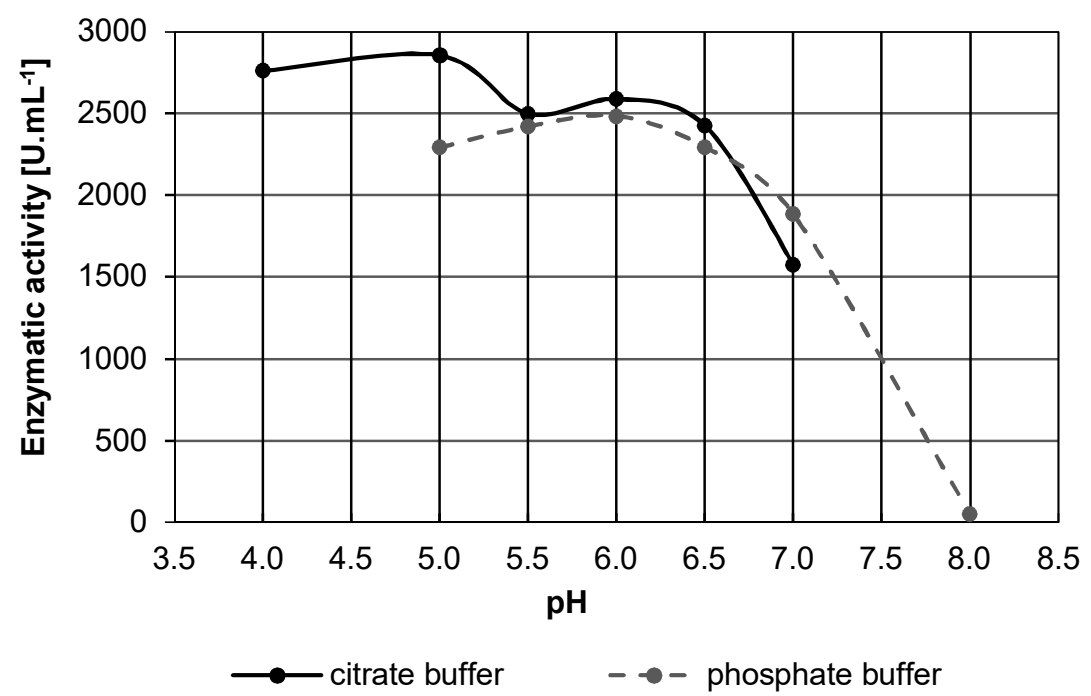

Figure 1. Effect of pH on PPO activity from faba bean coat

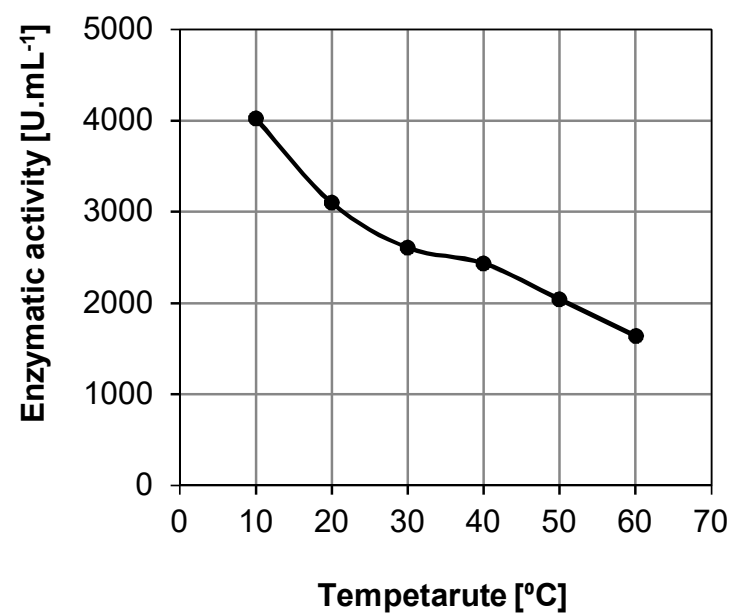

Figure 2. Effect of temperature on PPO activity from faba bean coat 
$\mathrm{K}_{\mathrm{m}}$ and $\mathrm{V}_{\max }$ values for PPO from faba bean coat for three phenolic compounds which generally use as substrates for polyphenol oxidase are presented in Table 2. From the $V_{\max } / K_{m}$ ratio the best substrates for PPO are catechol and pyrogallol. Paul and Gowda (2000) reported these $\mathrm{K}_{\mathrm{m}}$ values for field bean (Dolichos lablab var. lignosus) PPO; $1.18 \mathrm{mM}$ for L-DOPA, $4.0 \mathrm{mM}$ for 4-methylcatechol, $10.5 \mathrm{mM}$ for catechol and $12.5 \mathrm{mM}$ for pyrogallol. In another study carried out by Shin et al. (1997), $\mathrm{K}_{\mathrm{m}}$ values for mung bean leaf PPO were found to be $4 \mathrm{mM}$ for 4-methylcatechol and $24 \mathrm{mM}$ for L-DOPA. But $\mathrm{K}_{\mathrm{m}}$ value for green bean (Phaseolus vulgaris $\mathrm{L}$.) coat PPOIa and PPOIb was calculated 7.6-4.1 mM, 10.6-10.7 mM, 14.5-15.8 $\mathrm{mM}$ and 35.2-34.7 $\mathrm{mM}$ for pyrogallol, catechol, 4-methylcatechol and L-DOPA, respectively (Guo et al., 2009). According to literature, the interest of PPOs from various plant sources for various substrate varies widely.

Kinetic parameters of PPO from faba bean coat

Table 2

\begin{tabular}{|l|c|c|c|}
\hline \multicolumn{1}{|c|}{ Substrate } & $\mathbf{K}_{\mathbf{m}}[\mathbf{m M}]$ & $\mathbf{V}_{\mathbf{m a x}}\left[\mathbf{U} \cdot \mathbf{m L}^{-\mathbf{1}} \mathbf{d k}^{\mathbf{- 1}}\right]$ & $\mathbf{V}_{\mathbf{m a x}} / \mathbf{K}_{\mathbf{m}}$ \\
\hline Catechol & 5.53 & 4424.6 & 800.1 \\
\hline Pyrogallol & 3.05 & 2263.1 & 741.9 \\
\hline 4-methylcatechol & 12.18 & 2278.3 & 264.3 \\
\hline
\end{tabular}

PPO substrate specificity studied using eight well known substrates. Catechol showed maximum activity $\left(3370 \pm 135.4{\left.\mathrm{U} . \mathrm{ml}^{-1}\right)}^{-1}\right.$ and this was considered as $100 \%$ to compare its activity with other substrates (Table 3). The existence of hydroxyl groups in the case of catechol (-OH at ortho position, as in pyrogallol and 4-methylcatechol), the activity increased. By contrast, the substrates without catechol ring (-OH at meta or para positions) and with a functional group at other positions of the ring showed very less of activity. Pyrogallol and 4-methylcatechol were best substrates after the catechol. Optimum $\mathrm{pH}$ and optimum temperature study was performed for these substrates. For both substrates, the optimum $\mathrm{pH}$ was determined as 5.0 and the optimum temperature was $10^{\circ} \mathrm{C}$ as determined in the catechol substrate. Other Leguminosae PPO enzymes studied by the other researchers also showed high activity against catechol, 4-methylcatechol, pyrogallol and L-DOPA substrates (Shin et al., 1997; Paul and Gowda, 2000; Nagai and Suzuki, 2003; Guo et al., 2009).

Table 3

Substrate specificity of PPO from faba bean coat

\begin{tabular}{|c|c|c|}
\hline Substrate & Relative activity [\%] $]^{\mathrm{a}}$ & $\begin{array}{c}\text { Structural specificity of the } \\
\text { substrate }\end{array}$ \\
\hline Catechol & 100 & Ortho-dihydroxy $(1,2-\mathrm{OH})$ \\
\hline Pyrogallol & $81.8 \pm 3.3$ & Trihydroxy $(1,2,3-\mathrm{OH})$ \\
\hline 4-Methylcatechol & $77.2 \pm 0.6$ & Ortho-dihydroxy $\left(1,2-\mathrm{OH}, 4-\mathrm{CH}_{3}\right)$ \\
\hline Hydroquinone & $38.9 \pm 0.1$ & Para-dihydroxy $(1,4-\mathrm{OH})$ \\
\hline L-DOPA & $33.5 \pm 1.9$ & $\begin{array}{l}\text { Orto-dihydroxy }(1,2-\mathrm{OH}, 4-\mathrm{X}) \\
{\left[\mathrm{X}=\mathrm{CH}_{2}-\mathrm{CH}\left(\mathrm{NH}_{2}\right)-\mathrm{COOH}\right]}\end{array}$ \\
\hline Resorcin & $24.8 \pm 0.8$ & Meta-dihydroxy $(1,3-\mathrm{OH})$ \\
\hline Chlorogenic acid & $20.9 \pm 2.8$ & Ortho-dihydroxy $(1,2-\mathrm{OH})$ \\
\hline Gallic acid & $14.4 \pm 1.7$ & Trihydroxy $(1,2,3-\mathrm{OH}, 5-\mathrm{COOH})$ \\
\hline
\end{tabular}

${ }^{a}$ Each value represents the mean $\pm \mathrm{SD}(\mathrm{n}=3)$ 
For determine to $\mathrm{pH}$ stability, the enzyme solution was incubated in citrate buffer solutions ranging from 5.0 to 8.0 at $4{ }^{\circ} \mathrm{C}$ after $30 \mathrm{~min}$ and $60 \mathrm{~min}$ incubation period. The remaining enzyme activity was measured using catechol as substrate. At the end of the 60 minutes incubation period the highest activity was determined in the $\mathrm{pH} 5.0$ buffer that is the optimum $\mathrm{pH}$ of the enzyme, and the most activity loss was determined in $\mathrm{pH} 7.0$ buffer. As seen as in Figure 3, the remaining activity at pH 5.0 was $56 \%$, while at $\mathrm{pH} 6$ it was $41 \%$. The enzyme is not stable at $\mathrm{pH}$ 8.0. In the $\mathrm{pH}$ stability studies for PPO enzyme isolated from various sources, it was determined that they all showed the highest activity in buffers at their optimum pH (Mdluli, 2005; Gao et al., 2009; Kuyumcu, 2014).

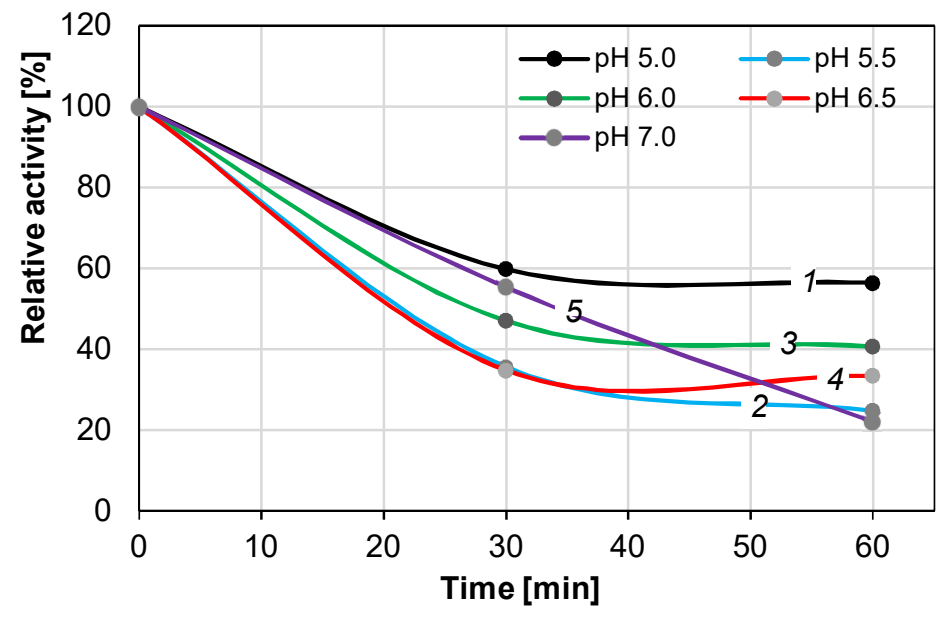

Figure 3. Effect of pH on stability of PPO activity (The residual activity of incubated enzyme expressed as\% relative activity):

$1-$ pH 5.0; 2 - pH 5.5; $3-$ pH 6.0; $4-$ pH 6.5; 5 - pH 7.0

Thermal inactivation of faba bean coat PPO was studied in the range $10-60{ }^{\circ} \mathrm{C}$, for different time periods $(15,30,45$ and $30 \mathrm{~min})$ as seen as Figure 4 . The enzyme was preserved its activity at $90 \%$ at $10{ }^{\circ} \mathrm{C}$ which was determined as the optimum temperature, and at $85 \%$ at $20^{\circ} \mathrm{C}$ where experimental studies were conducted. As stated in the study of Kuyumcu (2014) for mushroom PPO, after the incubations at optimum temperatures, the faba bean coat PPO has also substantially maintained its activity. The activity was maintained at $70 \%$ at 30 ${ }^{\circ} \mathrm{C}$ and $58 \%$ at $40{ }^{\circ} \mathrm{C}$ within the first 30 minutes, while enzyme activity decreased by half in the first 15 minutes at $50-60{ }^{\circ} \mathrm{C}$ (Figure 4). Therefore, it can be said the enzyme relatively thermostable. The results about the thermostability is in agreement with the results of the PPO study isolated from borage plant (Alici and Arabaci, 2016), quince (Yagar, 2004) and mulberry (Arslan et al., 2004). These results suggest that short incubation times could be worked at higher temperatures while longer incubation times should be chosen at low temperatures for food processes. 


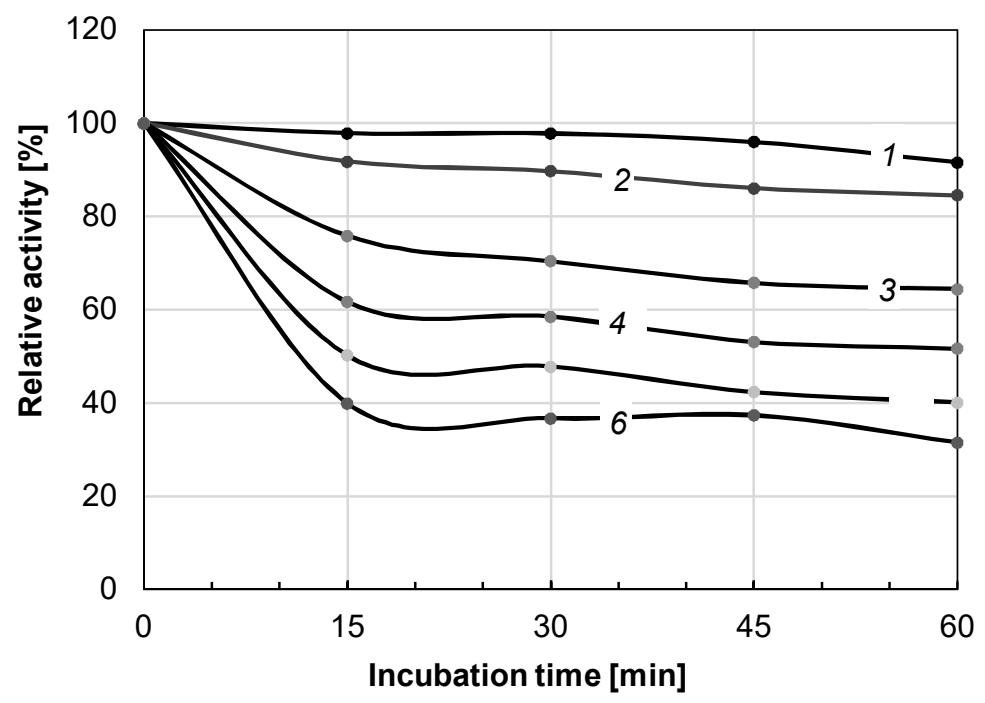

Figure 4. Effect of thermal treatments on PPO activity (The residual activity of incubated enzyme expressed as\% relative activity.)

Temperature, ${ }^{\circ} \mathrm{C}: 1-10 ; 2-20 ; 3-30 ; 4-40 ; 5-50 ; 6-60$.

In the study of ionic strength, it was observed that other metals, except the iron and cobalt ions, did not cause a major change in enzyme activity. While iron ion $(74.1 \pm 2.8 \%$ at $10 \mathrm{mM}$ and $92.4 \pm 2.4 \%$ at $1 \mathrm{mM}$ concentrations $)$ and cobalt ion $(72.1 \pm 1.8 \%$ at $1 \mathrm{mM}$ concentration) caused a decrease in enzyme activity, cobalt ion at $10 \mathrm{mM}$ concentration caused an increase of $10 \%$ in enzyme activity (Figure 5).

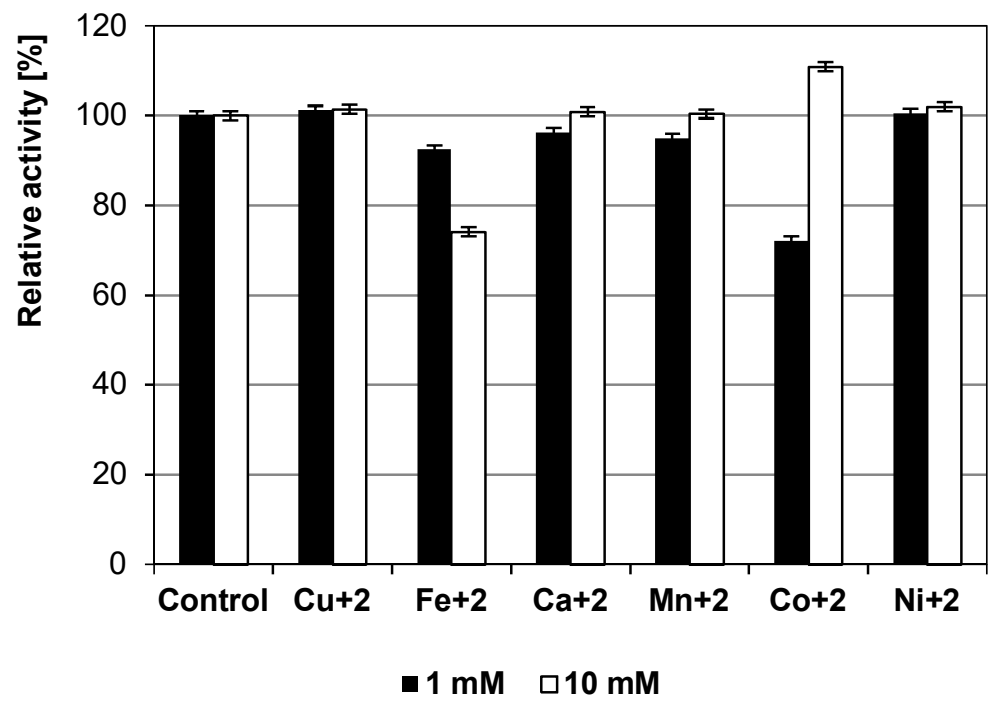

Figure 5. Effects of various metal ions on PPO activity 
It has been reported in the literature that $\mathrm{Cu}^{2+}, \mathrm{Hg}^{2+}, \mathrm{Mn}^{2+}, \mathrm{Zn}^{2+}, \mathrm{Al}^{3+}, \mathrm{Ni}^{2+}, \mathrm{Cd}^{2+}, \mathrm{Fe}^{3+}$, $\mathrm{K}^{+}, \mathrm{Ca}^{2+}$ ions at $1 \mathrm{mM}$ concentration have a different effect on the PPO from medlar fruit at different ripening stages (Ayaz et al., 2008). In the study conducted with the borage, it has been reported while some metals $\left(\mathrm{Fe}^{+3}, \mathrm{Mg}^{2+}, \mathrm{Pb}^{2+}, \mathrm{Zn}^{2+}, \mathrm{K}^{+}, \mathrm{Cu}^{2+}\right)$ increased PPO activity and some of them $\left(\mathrm{Hg}^{+2}, \mathrm{Mn}^{2+}, \mathrm{Ni}^{2+}, \mathrm{Na}^{+}\right)$decreased the activity at $1 \mathrm{mM}$ and $5 \mathrm{mM}$ ion concentrations (Alici and Arabaci, 2016). When the effect of $\mathrm{Na}^{+}, \mathrm{Hg}^{2+}, \mathrm{Mg}^{2+}, \mathrm{Ca}^{2+}, \mathrm{Mn}^{2+}$, $\mathrm{Ni}^{2+}, \mathrm{Co}^{2+}, \mathrm{Zn}^{2+}, \mathrm{Al}^{+3}$ ions (at the final concentrations of $1 \mathrm{mM}$ and $10 \mathrm{mM}$ ) on mushroom PPO activity was examined, the $\mathrm{Hg}^{2+}$ ion caused inhibition on PPO activity, by contrast with $\mathrm{Na}^{+}$ve $\mathrm{Al}^{3+}$ ions (Kuyumcu, 2014). Gao et al. (2009) reported a positive effect on the enzyme activity for $\mathrm{K}^{+}$and $\mathrm{Na}^{+}$ions for the PPO isolated from Swiss chard leaf; while $\mathrm{Mg}^{2+}, \mathrm{Ca}^{2+}$, $\mathrm{Cu}^{2+}, \mathrm{Mn}^{2+}, \mathrm{Co}^{2+}$ and $\mathrm{Zn}^{2+}$ ions had negative effects. These differences in the effects of metals on the catalytic activity of the enzyme may be due to the difference of metal solutions, the variety of metals and the different valences of metals (monovalent, divalent, trivalent), which makes it difficult to compare the researches.

In order to prolong the shelf life of fruits and vegetables and maintain their quality, various inhibitors are used to prevent enzymatic browning. In this study, the inhibitory effect of L-ascorbic acid, ethylenediamine tetraacetic acid (EDTA), sodium azide, L-cysteine, potassium cyanide and sodium bisulphite was showed on PPO activity (Figure 6). The highest inhibition rates have showed ascorbic acid $(78.2 \pm 2,1 \%)$ and sodium bisulphite $(73 \pm 2.14 \%)$ at a concentration of $6 \mathrm{mM}$; and sodium azide $(48.3 \pm 2.1 \%$ and $71 \pm 1.8 \%)$ and L-cysteine $(56 \pm 2.3 \%$ and $69 \pm 0.8 \%)$ at concentrations of $3 \mathrm{mM}$ and $6 \mathrm{mM}$. In the study, the $\mathrm{IC}_{50}$ value for L-cysteine the most common inhibitor of PPO, was found to be $50 \mathrm{mM}$. In many previous studies, ascorbic acid, sodium metabisulphite and L-cysteine have been reported to be effective inhibitors on plant-derived PPO enzymes (Paul and Gowda, 2000; Nagai and Suzuki, 2003; Guo et al., 2009).

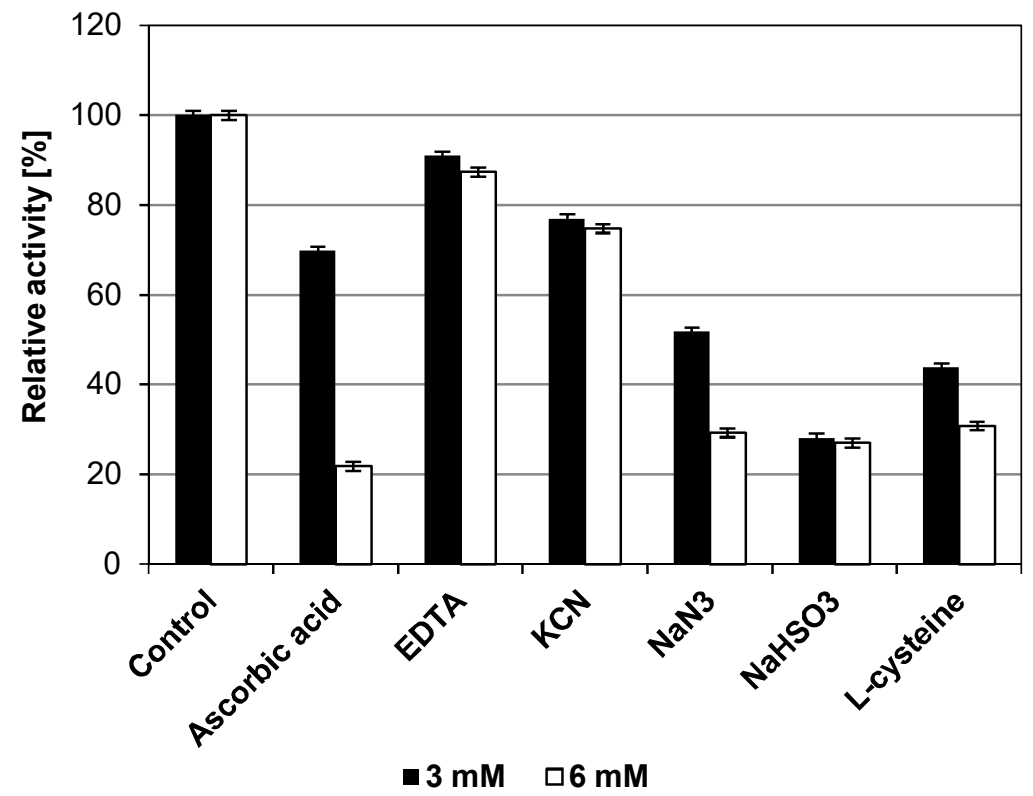

Figure 6. Inhibitor effect of chemicals on PPO activity from faba bean coat 
To investigation of the effect of storage stability of enzyme, partially purified PPO from faba bean coat was kept in $0.1 \mathrm{M}$ phosphate buffer $\left(\mathrm{pH}\right.$ 6.0) at $+4{ }^{\circ} \mathrm{C}$ over a month period. It was observed that the enzyme solution retained its activity about three weeks, and it lost $67 \%$ enzyme activity after 20 days (Figure 7). Our findings are similar to those of other authors. They reported that after storage at $+4{ }^{\circ} \mathrm{C}$, activity of PPO decreased about $97 \%$ for borage plant after 20 days (Alici and Arabaci, 2016), 90\% for blueberry after 3 weeks (Siddiq and Dolan, 2017) and 60\% for grape after a month (Onez, 2006), respectively. Nagai and Suzuki (2003), on the other hand, reported that activity of soybean sprouts PPO decreased after 8 days at $4{ }^{\circ} \mathrm{C}$.

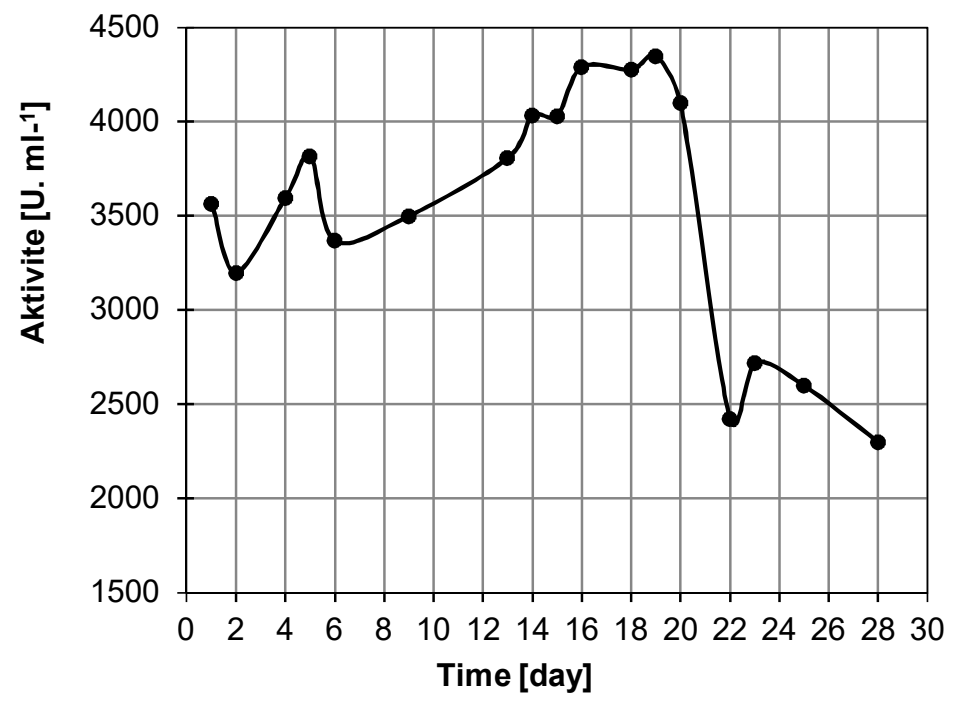

Figure 7. Inhibitor effect of storage time on the activity of faba bean coat PPO at $+4{ }^{\circ} \mathrm{C}$

In the literature, few studies have been reported on the isolation and characterization of PPO from faba bean leaf. These works cover investigations of PPO isoforms which have different isoelectric points and molecular weights (Robinson and Dry, 1992; Ganesa et al., 1992; Flurkey, 1989). However, there are studies on PPO from Fabaceae family including green bean (Guo et al., 2009), field bean (Paul and Gowda, 2000), mung bean (Shin et al., 1997) and soy bean sprouts (Nagai and Suzuki, 2003) from the same family with faba bean. On the other hand, Ozcan and Sagiroglu (2014) have designed a biosensor for the determination of phenolic compounds by immobilizing the faba bean shell homogenate to the glassy carbon electrode surface. In their study, various phenolic compounds (catechol, pcresol, caffeic acid, hydroquinone, pyrogallol, cinnamic acid) were oxidized by the PPO enzyme in the faba bean coat tissue. In the literature, no studies have been conducted on faba bean pod except this amperometric based biosensor study. In future work, it is considered to develop other biosensors in which this plant is used as an enzyme source. 


\section{Conclusion}

Polyphenol oxidase has notable, since it is the key enzyme responsible for browning and defencing system in the plant kingdom. The researches on PPO can lead to understanding this enzyme that catalyses the browning reaction. Therefore, it is important to understand the biochemical properties of polyphenol oxidase, which is a food quality related enzyme. It was our aim to determine some properties of PPO from faba bean coat such as optimum $\mathrm{pH}$, optimum temperature, substrate specificity, kinetic values, thermal stability, effect of some chemicals and metal ions on enzyme activity. The results demonstrate that the enzyme has heat stability and the possibility of being used to construct biosensors and other analytical methods in various fields. The most effective inhibitors were ascorbic acid and sodium bisulfite, and $\mathrm{Fe}^{2+}$ ions caused a decrease in the PPO activity. In conclusion, the enzymatic characterization of the PPO from faba bean coat was defined by us for the first time, and it may help to better understand the PPO enzyme, especially in food industry.

Financing. This research work was supported financially by the Chemistry Department of Trakya University, Turkey.

\section{References}

Alici E.H., Arabaci G. (2016), Purification of polyphenol oxidase from borage (Trachystemon orientalis L.) by using three-phase partitioning and investigation of kinetic properties, International Journal of Biological Macromolecules, 93, pp. 10511056, DOI:10.1016/j.ijbiomac.2016.09.070.

Antongiovanni M., Acciaioli A., Franci O., Paola Ponzetta M., Pugliese C., Buccioni A., Badii M. (2002), Field bean (Vicia faba var. minor) as a protein feed for growing lambs with and without protected lysine and methionine supplementation, Italian Journal of Animal Science, 1(3), pp. 229-238, DOI: 10.4081/ijas.2002.229

Arslan O., Erzengin M., Sinan S., Ozensoy O. (2004), Purification of mulberry (Morus alba L.) polyphenol oxidase by affinity chromatography and investigation of its kinetic and electrophoretic properties, Food Chemisrty, 88(3), pp. 479-484, DOI:10.1016/j.foodchem.2004.04.005

Ayaz F.A., Demir O., Torun H., Kolcuoglu Y., Colak, A. (2008), Characterization of polyphenoloxidase (PPO) and total phenolic contents in medlar (Mespilus germanica L.) fruit during ripening and over ripening, Food Chemisrty, 106(1), pp. 291-298, DOI:10.1016/j.foodchem.2007.05.096

Ayaz F.A., Sökmen A. (2015), Plant Biochemistry, Nobel Academic Publishing: Ankara.

Bradford M.M. (1976), A Rapid and sensitive method for the quantitation of microgram quantities of protein utilizing the principle of protein-dye binding, Analitical Biochemistry, 72, pp. 248-254.

Chen Y., Ni X., Cottrell T.E., Wood B.W., Buntin G.D. (2009), Changes of oxidase and hydrolase activities in pecan leaves elicited by black pecan aphid (Hemiptera: Aphididae) feeding, Journal of Economic Entomology, 102(3), pp. 1262-1269, DOI: 10.1603/029.102.0353

Constabel C.P., Barbehenn R. (2008), Defensive Roles of Polyphenol Oxidase in Plants, In: Schaller A. Ed., Induced Plant Resistance to Herbivory, Springer, Berlin, pp. 253-269. ISBN: 978-1-4020-8182-8. 
Flurkey W.H. (1989), Polypeptide composition and amino-terminal sequence of broad bean polyphenol oxidase, Plant Physiology, 91(2), pp. 481-483.

Ganesa C., Fox M.T., Flurkey W.H. (1992), Microheterogeneity in purified broad bean polyphenol oxidase, Plant Physiology, 98(2), pp. 472-479, DOI: 10.1104/pp.98.2.472

Gao Z.J., Han X.H., Xiao X.G. (2009), Purification and characterisation of polyphenol oxidase from red Swiss chard (Beta vulgaris subspecies cicla) leaves, Food Chemisrty, 117, pp. 342-348, DOI:10.1016/j.foodchem.2009.04.013

Goyoaga C., Burbano C., Cuadrado C., Varela A., Guillamón E., Pedrosa M.M., Muzquiz M. (2008), Content and distribution of vicine, convicine and L-DOPA during germination and seedling growth of two Vicia faba L. varieties, European Food Research and Technology, 227, pp. 1537-1542, DOI:10.1007/800217-008-0876-0

Guo L., Ma Y., Shi J., Xue S. (2009), The purification and characterisation of polyphenol oxidase from green bean (Phaseolus vulgaris L.), Food Chemistry, 117 (1), pp. 143151, DOI:10.1016/j_foodchem.2009.03.088

He J., Chen F., Chen S., Lv G., Deng Y., Fang W., Liu Z., Guan Z., He C. (2011), Chrysanthemum leaf epidermal surface morphology and antioxidant and defense enzyme activity in response to aphid infestation, Journal of Plant Physiology, 168(7), pp. 687-693, DOI: 10.1016/j.jplph.2010.10.009

Ionita E., Gurgu L., Aprodu I., Stanciuc N., Dalmadi I., Bahrim G., Rapeanu G. (2017), Characterization, purification, and temperature/pressure stability of polyphenol oxidase extracted from plums (Prunus domestica), Process Biochemistry, 56, pp. 177-185, DOI: 10.1016/j.procbio.2017.02.014

Kuyumcu I. (2014), Purification and characterization of polyphenol oxidase from a wild edible mushroom Lactarius eucalypti, Karadeniz Technical University, Trabzon.

Mdluli K.M. (2005), Partial purification and characterisation of polyphenol oxidase and peroxidase from marula fruit (Sclerocarya birrea subsp. Caffra), Food Chemistry, 92, pp. 311-323, DOI:10.1016/j.foodchem.2004.07.026

Mohseni S.M., Golshani B. (2013), Simultaneous determination of Levodopa and Carbidopa from fava bean, green peas and green beans by HPLG chromatography, Journal of Clinical and Diagnostic Research, 7(6), pp. 1004-1007, DOI: 10.7860/JCDR/2013/5415.3072

Nabity P.D., Heng-Moss T.M., Higley L.G. (2006), Effects of insect herbivory on physiological and biochemical (Oxidative enzyme) responses of the halophyte Atriplex subspicata (Chenopodiaceae), Environmental Entomology, 35(6), pp. 1677-1689, DOI: 10.1093/ee/35.6.1677

Nagai T., Suzuki N. (2003), Polyphenol oxidase from bean sprouts (Glycine max L.), Food and Chemical Toxicology, 68(1), pp. 16-20, DOI: 10.1111/j.13652621.2003.tb14107.x

NC-IUBMB (Nomenclature Committee of the International Union of Biochemistry and Molecular Biology) 2019, Available at: https://iubmb.qmul.ac.uk/enzyme/EC1/

Ng A.W.R., Wong C.W. (2015), Partial purification and characterization of polyphenol oxidase from round brinjal (S. melongena var. depressum), International Food Research Journal, 22(2), pp. 826-831.

Onez Z. (2006), Isolation and properties of grape (Vitis vinifera L.) polyphenol oxidase, Ankara University, Ankara.

Ozcan H., Sagiroglu A. (2014), Fresh broad (Vicia faba) tissue homogenate based biosensor for determination of phenolic compounds, Artificial Cells, Nanomedicine and Biotechnology, 42(4), pp. 256-261, DOI:10.3109/21691401.2013.764313 
Panadare D., Rathod VK. (2018), Extraction and purification of polyphenol oxidase: A review, Biocatalysis and Agricultural Biotechnology, 14, pp. 431-437, DOI: 10.1016/j.bcab.2018.03.010

Park E.Y., Luh B.S. (1985), Polyphenol oxidase of kiwifruit, Journal of Food Science, 50, pp. 678-684.

Paul B., Gowda L.R. (2000), Purification and characterization of a polyphenol oxidase from the seeds of field bean (Dolichos lablab), Journal of Agricultural Food Chemistry, 48(9), pp. 3839-3846, DOI:10.1021/jf000296s.

Perella F., Mugnai C., Dal Bosco A., Sirri F., Cestola E., Castellini C. (2009), Faba bean (Vicia faba var. minor) as a protein source for organic chickens: Performance and carcass characteristics, Italian Journal of Animal Science, 8(4), pp. 575-584, DOI: $10.4081 /$ ijas.2009.575

Robinson S.P., Dry I.B. (1992), Broad bean leaf polyphenol oxidase is a 60-kilodalton protein susceptible to proteolytic leavage, Plant Physiology, 99(1), pp. 317-323, DOI: $10.1104 /$ pp.99.1.317

Shin R., Froderman T., Flurkey W.H. (1997), Isolation and characterization of a mung bean leaf polyphenol oxidase, Phytochemistry, 45(1), pp. 15-21, DOI: 10.1016/S00319422(96)00785-6

Siddiq M., Dolan K.D. (2017), Characterization of polyphenol oxidase from blueberry (Vaccinium corymbosum L.). Food Chemistry, 218, pp. 216-220, DOI: 10.1016/j.foodchem.2016.09.061

Soffan A., Alghamdi SS., Aldawood A.S. (2014), Peroxidase and polyphenol oxidase activity in moderate resistant and susceptible Vicia faba induced by Aphis craccivora (Hemiptera: Aphididae) infestation, Journal of Insect Science, 14(285), pp. 1-6, DOI: $10.1093 /$ jisesa/ieu147

Topal N., Bozoglu H. (2016), Determination of L-DOPA (L-3, 4-dihydroxyphenylalanine) content of some faba bean (Vicia faba L.) genotypes, Journal of Agricultural Science, 22(1), pp. 145-151, DOI:10.1501/Tarimbil 0000001376

Turco I., Ferretti G., Bacchetti T. (2016), Review of the health benefits of faba bean (Vicia faba L.) polyphenols, Journal of Food and Nutrition Research, 55(4), pp. 283-293.

Yagar H. (2004), Some biochemical properties of polyphenol oxidase from celery, Preparative Biochemistry \& Biotechnology, 34(4), pp. 387-397, DOI:10.1081/PB200031054

Yilmaz M., Sahin S. (2014), Assesment of effect of faba bean (Vicia faba L.) using as green manure on yield of broccoli, Journal of Agricultural Faculty of Gaziosmanpasa University, 31(1), pp. 85-93, DOI:10.13002/jafag727 